\title{
Habitat restoration as mitigation for lost production at multiple trophic levels
}

\author{
Deborah P. French McCay*, Jill J. Rowe
}

Applied Science Associates, 70 Dean Knauss Drive, Narragansett, Rhode Island 02882, USA

\begin{abstract}
Seagrass beds and salt marshes are important in the life histories of many fish, invertebrates, and aquatic birds, such that population size and production of these organisms can be limited by the loss of these habitats. Therefore, restoring seagrass or salt marsh would be expected to benefit species dependent on these resources. Following the 'North Cape' oil spill of January 1996 in Rhode Island (northeastern USA), habitat restoration was used to compensate for losses of fish, invertebrates, and aquatic birds. A habitat restoration model based on food-chain transfers was used to estimate equivalent production at the same trophic level as the losses, a novel approach that uses energetic efficiencies to scale across trophic levels. Benefits of habitat to each trophic level were estimated by assuming that the production of consumers is proportional to prey production gained by the restoration of habitat. The habitat restoration model balanced the losses with trophically equivalent production, discounting future gains in compensatory production relative to present losses such that interest is paid, analogous to economic discounting. Results showed that restoration of seagrass beds would be more productive than salt marsh restoration in southern New England and, likely, other temperate zone locations. Moreover, benthic faunal production in salt marshes could be accounted for by in situ primary production of angiosperms and benthic microalgae, whereas in seagrass beds, benthic faunal production exceeded that expected from in-bed primary production. The trophic model provides a methodology to estimate the scale of a restoration project that will provide production (ecological services) equivalent to losses of organisms at multiple trophic levels, applicable to natural resource damage assessments and other environmental assessments.
\end{abstract}

KEY WORDS: Restoration · Habitat - 'North Cape' oil spill · Natural resource damage assessment . Trophic transfer $\cdot$ Food web modeling

\section{INTRODUCTION}

In response to pervasive degradation of coastal marine ecosystems, especially including vegetated and other structured habitats, such as seagrass and wetlands of great importance as larval settlement areas, nurseries, refugia from predation, and foraging habitats (Heck \& Orth 1980, Kneib 1997, Beck et al. 2001, Heck et al. 2003, Minello et al. 2003), considerable interest has developed in their protection and restoration (Thayer 1992, Matthews \& Minello 1994, Fonseca et al. 1998, Beck et al. 2003). In the USA, when natural resources are impacted by environmental incidents, such as oil and chemical spills, pollutant relea- ses, or physical destruction of habitat, federal and state agents are legally mandated to obtain funds from responsible parties to restore equivalent ecological and human services (NOAA 2002). Because restoration of highly productive structural habitats such as seagrass and salt marsh would benefit dependent fish, invertebrates, birds, and other wildlife, and these habitats have suffered great losses from eutrophication and other perturbations (e.g. Orth \& Moore 1983), salt marsh or seagrass restoration is often the preferred choice for compensation of injuries to natural resources in coastal marine ecosystems.

Estimation of the benefits of habitat restoration is rarely performed to render the scale of the restoration 
project compensatory (equivalent in value to the loss). Here we develop a method for estimating the appropriate scale of restoration, and demonstrate the approach by application to the 'North Cape' oil spill, which occurred in January 1996 on the Rhode Island coast (northeastern USA). The habitat restoration model builds upon food chain energetics (e.g. Slobodkin 1960, Ryther 1969, Odum 1971, Steele 1974, Odum \& Heald 1975) and habitat equivalency analysis (HEA: NOAA 1997, 1999, Julius 1999). Our model converts losses of production of multiple species to an energetically equivalent single trophic level so that the scale of necessary compensatory restoration can be computed. Data required for the model include the net gain in primary production expected from restoration of the structured habitat, the food web structure, and energetic transfer efficiencies. Assuming that augmentation of production of consumers is proportional to net gains in production of their prey (i.e. the consumers' production is food-limited), we estimate the production benefits to each higher trophic level. HEA is a modeling approach that translates lost or gained ecological and human services to present-day value by applying the economic concept of discounting, to account for the delay in benefits between the time of loss and the gain in production (Julius 1999, NOAA 1999).

We structure this paper as follows: First, we summarize the injury estimation methods and results for the 'North Cape' oil spill. Next, we review restoration options and develop the habitat restoration model approach, including specific methods for estimating the scale of restoration required to compensate an injury comprised of species of multiple trophic levels. The results of application of the restoration model to the 'North Cape' oil spill are described, along with more general implications of comparing salt marsh and eelgrass bed food webs. Finally, we characterize sensitivity of model results to its assumptions and the implications for effectively restoring losses resulting from environmental impacts.

\section{INJURY ESTIMATION}

The 'North Cape' oil spill was a release of 2682 metric tons (828 000 gallons; $3130 \mathrm{~m}^{3}$ ) of home heating (No. 2 fuel) oil into heavy surf, resulting in high concentrations of polynuclear aromatic hydrocarbons (PAHs) in shallow water that caused severe acute mortality by narcosis (French McCay 2002, 2003). The majority of the impact (measured as biomass lost) was to near-shore benthic marine invertebrates (American lobster Homarus americanus; rock crabs Cancer spp.; blue mussel Mytilus edulis; sea stars; surf clam Spisula solidissima; and benthic amphipods) and fishes associ- ated with rocky reefs (tautog Tautoga onitis; and cunner Tautogolabrus adspersus) along the exposed southern coast of Rhode Island (French McCay 2003). PAHs from the oil also entered coastal lagoons ('salt ponds') behind the impacted barrier beaches, killing soft-shell clams Mya arenaria, American oysters Crassostrea virginica, bay scallops Argopecten irradians, other invertebrates and fish (French \& Rines 1998). Four hundred oiled birds were collected after the spill, indicating several thousand killed by direct oiling, based on recovery rates of beached birds (NOAA et al. 1999) and modeling of the area swept by oil multiplied by species density (French McCay 2003). Because the oil was quickly and effectively dispersed by high turbulence and waves, impacts were primarily from acute exposure to dispersed and dissolved oil concentrations (fish and invertebrates) and oil sheens (birds), rather than chronic contamination. Wetlands and seagrass beds were not significantly impacted by the spill.

Modeling of oil fates and biological effects was used (French McCay 2003) to estimate mortalities of marine organisms. A physical-fates model predicted water column PAH concentrations, which were validated with field sampling results. A linked biological effects model estimated acute exposure (concentrations and duration) to oil PAHs and resulting mortality. The modeled estimate of lobster mortality (8.3 million: French McCay 2003) was similar to estimated numbers of lobsters killed based on field sampling (9.0 million: Cobb et al. 1999), validating the biological effects model (French McCay 2003). The model was used to calculate injury (as biomass lost) to other marine organisms, based on estimates of biomass density, size structure, growth rate and mortality rates (French et al. 1996a, French McCay 2003, French McCay et al. 2003b, in this Theme Section).

PAH concentrations in each of the salt ponds over time were estimated by Hinga (1997) by fitting exponential decay curves to measured concentrations to account for volatilization and degradation (Hinga 1988), using source contamination estimated by the marine modeling (French McCay 2003). Exposure and mortality of biota were estimated using the biological effects model (French McCay 2002, 2003) and pre-spill abundance in each pond (French \& Rines 1998).

Injuries ( $\mathrm{kg}$ wet weight) to fish and invertebrates in the marine environment and the salt ponds are summarized in Tables 1 \& 2, calculated as the sum of the biomass killed, which represents net production realized previous to the spill, and lost future production that the killed organisms are expected to have provided had they not been killed (production foregone). Production forgone was estimated using a demographic population model (French McCay et al. 2003b), where somatic growth was summed over age classes (indexed 
Table 1. Injuries (kg wet weight, without shells) in the marine environment (Block Island Sound) resulting from the 'North Cape' oil spill, estimated by field data collections (lobsters: Cobb et al. 1999) or ecotoxicological modeling of oil fates and effects (other species: French McCay 2003). Production foregone is estimated by summing somatic growth over the remaining lifespan of the killed individuals by annual age class. -: not estimated

\begin{tabular}{|c|c|c|c|c|}
\hline Species category & $\begin{array}{l}\text { Number killed } \\
\qquad\left(\times 10^{3}\right)\end{array}$ & $\begin{array}{l}\text { Biomass } \\
\text { killed (kg) }\end{array}$ & $\begin{array}{c}\text { Production } \\
\text { foregone }(\mathrm{kg})\end{array}$ & $\begin{array}{l}\text { Total injury } \\
\quad(\mathrm{kg})\end{array}$ \\
\hline Alewife Alosa pseudoharengus & 0.01 & 3 & 3 & 6 \\
\hline Herring (sea) Clupea harengus harengus & 392 & 3040 & 4190 & 7240 \\
\hline Hakes (red and white) Urophycis spp. & 1.7 & 125 & 824 & 949 \\
\hline Cod Gadus morhus & 3.6 & 350 & 1250 & 1600 \\
\hline Spiny dogfish Squalus acanthias & 0.46 & 1 & 194 & 195 \\
\hline Haddock Melanogrammus aeglefinus & 0.005 & 4 & 3 & 7 \\
\hline Atlantic pollock Pollachius virens & 0.24 & 2 & 3 & 4 \\
\hline Northern searobin Prionotus carolinus & 12.2 & 94 & 130 & 225 \\
\hline Silver hake Merluccius bilinearis & 5.0 & 39 & 53 & 92 \\
\hline Ocean pout Macrozoarces americanus & 45 & 351 & 484 & 835 \\
\hline Flounders (Pleuronectidae) & 0.55 & 480 & 398 & 879 \\
\hline Sculpin Myoxocephalus octodecimspinos & 28.6 & 222 & 306 & 529 \\
\hline Skates Raja spp. & 1950 & 15130 & 20800 & 35980 \\
\hline Tautog Tautoga onitis & 16.5 & 459 & 544 & 1000 \\
\hline Cunner Tautogolabrus adspersus & 1740 & 9758 & 51300 & 61000 \\
\hline Crabs (rock) Cancer spp. & 3890 & 41730 & 49300 & 91010 \\
\hline Crabs (hermit) Pagurus spp. & 3730 & 3732 & 2430 & 6160 \\
\hline American lobster Homarus americanus & 9040 & 312400 & - & 312400 \\
\hline Northern quahog larvae Mercenaria mercenaria & 37.5 & 7 & 798 & 805 \\
\hline Atlantic surf clam Spisula solidissima & 150600 & 192500 & 172000 & 364000 \\
\hline Blue mussel Mytilus edulis & 20250 & 879 & 1200 & 2080 \\
\hline Sea stars Asterias forbesi and Henricia sanguinolenta & 2460 & 24580 & 6880 & 31460 \\
\hline Benthic macrofauna & 4890000 & 489000 & 310500 & 799500 \\
\hline Total & 5084000 & 1095000 & 623000 & 1718000 \\
\hline
\end{tabular}

Table 2. Injuries (kg wet weight, without shells) in the salt ponds resulting from the 'North Cape' oil spill (French \& Rines 1998). Production foregone is estimated by summing somatic growth over the remaining lifespan of the killed individuals by annual age class. -: not estimated

\begin{tabular}{|c|c|c|c|c|}
\hline Species category & $\begin{array}{l}\text { Number killed } \\
\left.\qquad \times 10^{3}\right)\end{array}$ & $\begin{array}{l}\text { Biomass } \\
\text { killed (kg) }\end{array}$ & $\begin{array}{c}\text { Production } \\
\text { foregone }(\mathrm{kg})\end{array}$ & $\begin{array}{l}\text { Total injury } \\
\quad(\mathrm{kg})\end{array}$ \\
\hline Winter flounder Pseudopleuronectes americanus & 1.59 & 1377 & 1142 & 2519 \\
\hline Forage fish (Cyprinodontidae) Menidia spp. & 533 & 2667 & 2370 & 5037 \\
\hline Northern quahog Mercenaria mercenaria & - & - & - & - \\
\hline Soft shell clam Mya arenaria & 499 & 5712 & 3888 & 9600 \\
\hline Eastern oyster Crassostrea virginica & 149 & 1857 & 905 & 2762 \\
\hline Bay scallop Argopecten irradians & 0.16 & 5 & 0 & 5 \\
\hline Crabs Cancer spp. & 318 & 3181 & 3756 & 6937 \\
\hline Grass shrimp Palaemonetes spp. & 324 & 81 & 88 & 169 \\
\hline Zooplankton & 5397 & 229 & - & 229 \\
\hline Benthic macrofauna & 6591800 & 65920 & 98110 & 164030 \\
\hline Total & 6599000 & 81030 & 110260 & 191290 \\
\hline
\end{tabular}

at the midpoint of each year of life, i.e. in winter), accounting for survival and discounting of future losses. For lobsters and bivalves, abundance data and parameters for the demographic model are described in French McCay (2003) and French McCay et al. (2003a,b, in this Theme Section). The demographic model parameters of the other fish and invertebrate species were from French et al. (1996a), with abundances in the marine environment as described in French McCay (2003). Abundance of non-bivalve species in the salt ponds was based on previous studies in the specific ponds affected (French \& Rines 1998). 


\section{ALTERNATIVES FOR RESTORATION}

\section{Restoration approaches to compensate for injuries}

Following the 'North Cape' oil spill, lobsters and bivalves were restored by species-specific restocking programs, described in French McCay et al. (2003a,b). Sea stars were assumed restored by restoration of their prey, the bivalves. For species other than lobsters, bivalves and sea stars, the trustees responsible for restoration of resources injured during the 'North Cape' spill determined that injuries were not large enough, or that restocking methods were not sufficiently developed (e.g. benthic amphipods, skates, and cunner), to warrant species-specific restoration projects (NOAA et al. 1999). Because many of these species would benefit from the production, refuge and nursery services of structured habitats, habitat restoration projects were considered, specifically for salt marsh (dominated by Spartina alterniflora and S. patens) and seagrass beds (eelgrass Zostera marina), the most important structured habitats in southern New England marine and estuarine waters.

Of the 2000 to 3000 aquatic birds killed by the 'North Cape' oil spill, ca. 200 were of species that normally forage in the salt ponds, wetlands and seagrass beds (Table 3). These species were restored by habitat restoration, along with the fish and invertebrates not included in species-specific restorations. Expressed as wet weight production lost, the total 'pond' bird injury was $476 \mathrm{~kg}$, with estimates of average weight per bird from French et al. (1996a). It is assumed that these birds were fully grown, so there is no additional production (foregone) from weight gain expected over their remaining lifetime. Additional losses of birds were compensated by restoration targeted at increasing fledgling production of eiders, loons, and piping plovers (NOAA et al. 1999).

Table 3. Estimated bird injury for species that use the salt ponds, wetlands and seagrass beds for foraging, expressed as numbers and kg (wet weight) of injury. Average wet weight per bird is from French et al. (1996a)

\begin{tabular}{|lccr|}
\hline Species & $\begin{array}{c}\text { Number } \\
\text { killed }\end{array}$ & $\begin{array}{c}\text { Mean weight } \\
\text { ind. }^{-1}(\mathrm{~kg})\end{array}$ & $\begin{array}{c}\text { Injury } \\
(\mathrm{kg})\end{array}$ \\
\hline Black duck Anas rubripes & 30 & 0.8 & 24 \\
Coot Fulica americana & 6 & 0.8 & 5 \\
Mallard Anas platyrhynchos & 18 & 0.8 & 14 \\
Pintail Anas acuta & 12 & 0.8 & 10 \\
Ruddy duck Oxyura jamaicensis & 12 & 0.8 & 10 \\
Canadian geese Branta canadensis & 36 & 5 & 180 \\
Swans (Anatidae: Cygninae) & 24 & 6.7 & 161 \\
Scaups Aythya spp. & 24 & 1.1 & 26 \\
Herons (Ardeidae) & 36 & 1.3 & 47 \\
Total & 198 & & 476 \\
\hline
\end{tabular}

\section{Development of function in created marshes and seagrass beds}

The degree to which ecological functions of created salt marshes match natural habitat depends on how well geomorphology and hydrology mimic natural systems (Seneca \& Broome 1992, Zedler 1992, Minello \& Webb 1997, Williams \& Zedler 1999). Assuming that appropriate geomorphology and hydrology are recreated, the time for recovery of function depends on the parameters measured: vegetation develops rapidly and fish populate new salt marsh habitat at natural levels in as little as 2 to $5 \mathrm{yr}$, but invertebrates, sediment chemisty and nutrient cycling take longer to become equivalent to natural systems (Moy \& Levin 1991, Minello \& Zimmerman 1992, Zedler 1992, Williams \& Zedler 1999). Restoring tidal flows in systems degraded by tidal restrictions and impoundments will bring back fully functioning tidal salt marshes in 1 to 2 decades (Warren et al. 2002). In the 'North Cape' restoration planning, it was assumed that salt marsh restoration would produce habitat with appropriate geomorphology, hydrology, and biology (dominated by Spartina alterniflora), and that after $15 \mathrm{yr}$ ecological functions would reach $99 \%$ of full function. This recovery period is based on studies of salt marsh functional recovery rates in California, North Carolina and France (PERL 1990, Seneca \& Broome 1992, Zedler 1992, French et al. 1996b).

Successful seagrass bed restoration is contingent on good water quality, as well as appropriate site selection, planting techniques, monitoring and corrective actions as needed (Fonseca et al. 1998). Fonseca et al. (1990) found fish and shrimp abundance in restored eelgrass beds indistinguishable from natural beds 6 mo after seeding or $2 \mathrm{yr}$ after transplanting eelgrass. Abundance in the eelgrass was higher than over unvegetated bottom. For the 'North Cape' restoration planning calculations, created seagrass beds were assumed to be transplanted into appropriate sites and to require $3 \mathrm{yr}$ to develop full (99\%) function, based on the recent restoration projects reviewed by Fonseca et al. (1998).

\section{Creation versus preservation}

Although planting seagrass is not technically complex and seagrass beds can be created under appropriate conditions, preservation (prevention of loss) is the most effective and reliable process to sustain seagrass habitat and associated resources (Fonseca et al. 
1998). Restoration of salt marsh grasses is also feasible, but full function of created marshes takes many years or may never be achieved (Seneca \& Broome 1992, Zedler 1992), rendering preservation preferable to mitigation of (purposeful) marsh loss. However, preservation can only be used as compensatory mitigation for an environmental incident where imminent loss of habitat would otherwise occur. If not, there would be no net gain in ecosystem services to match the losses.

Such an opportunity for prevention of imminent loss of seagrass habitat was available in southern Rhode Island near the 'North Cape' oil spill site. Seagrass habitat has declined generally throughout the estuaries of the Atlantic coast of North America, largely in response to eutrophication (Orth \& Moore 1983, Short \& Burdick 1996, Short et al. 1996). Using an approach developed for a Massachusetts estuary (Short \& Burdick 1996), Short et al. (1996) evaluated whether the condition and status of eelgrass Zostera marina habitat changed as a function of increasing housing development in the watershed of a shallow coastal lagoon, Ninigret Pond, in Rhode Island over a 32 yr period. In that time, housing quadrupled and eelgrass beds declined by $41 \%$. Short et al. (1996) linked nutrient flow from home septic systems to the decline in eelgrass, suggesting that eutrophication caused an inverse relationship between seagrass area and housing, and concluding that further development is likely to cause more losses of eelgrass. This relationship is supported by nutrient enrichment studies in mesocosms, where eelgrass growth decreased with nitrate enrichment (Burkholder et al. 1992, Short et al. 1995). Thus, instead of constructing new eelgrass beds, compensation for injuries could be achieved by avoiding future losses (preservation) through land acquisition and protection from development.

\section{METHODS FOR SCALING HABITAT RESTORATION ALTERNATIVES}

\section{Scaling restoration based on equivalent production}

The approach used in the 'North Cape' case was that the restoration project (of sufficient scale to compensate the injury to fish, invertebrates other than lobsters and bivalves, and 'pond' birds) would be implemented in one or more of the salt ponds affected and/or adjacent to the area of the marine injuries. The ecological and human services provided by the injured organisms were measured by production, biomass directly lost plus that not produced. Many ecosystem and human services increase in proportion to biological productivity. Particularly in aquatic ecosystems, the rate of turn- over (production) is a better measure of ecological services than density or biomass (Odum 1971, Beck et al. 2003). Thus, the sum of the standing-stock killed (production previous to the spill) plus loss of expected future production is an appropriate metric for computing lost ecological services. Using production as the scaling metric also allows for differences in body size and growth rate between the individuals killed and the ones added by restoration while still achieving equivalence and thus compensatory replacement.

Our trophic model for quantifying benefits of habitat restoration (or preservation) is designed to account for the different ecological values of the production as a function of trophic level. The production losses for each of the injured species are translated to a common lower trophic level (primary or secondary) via simple energetics and a food web model so that production of that lower trophic level can represent the metric used to scale the size of the habitat restoration project. This approach is based on the assumption that the entire food web benefits from the additional primary or secondary production contributed by the restored habitat, i.e. that consumers at each trophic level are foodlimited. Compensation is needed for lost production of each species injured, and those losses are additive. Restoration for a prey species killed will compensate for that prey killed and all the services that prey would have provided in the future to its predators and other resources. The predators that would eat that prey but were directly killed were produced before the spill by eating different prey individuals as food. Thus, compensation must include both the predator's production loss and that of the prey animals directly killed. This can be accomplished by providing additional prey production to compensate for the direct predator loss and resulting production foregone.

Correction for the delay between the injury occurrence and its restoration was achieved through discounting at a $3 \%$ (NOAA 1997) annual rate. The restoration project should be of a scale to provide production, in present day value (i.e. in the year of the spill), equivalent to the present day value of the direct kill plus production foregone. Two types of time lags are compensated: (1) the time from the spill to commencement of restoration, and (2) the time for the restored habitat to develop full function (with partial credit while it develops).

\section{Habitat restoration model}

Primary production is used to measure the benefits of the restoration project, such that in the habitat restoration model the total injuries in $\mathrm{kg}$ of lost production are translated into equivalent plant production. 
The majority of the primary production is by angiosperms Spartina alterniflora and $S$. patens in salt marshes and Zostera marina in eelgrass beds of the northeastern USA (Teal 1962, Howes et al. 1985, Adam 1993, Fonseca et al. 1998). However, in both salt marshes and seagrass beds, benthic and epiphytic microalgae provide an important, more readily assimilated form of primary production (Thayer et al. 1984, Currin et al. 1995, Sullivan \& Currin 2000). The model assumes that net primary production of phytoplankton and macroalgae are not significantly different in the restored and previously existing habitat, such that the restoration does not change those energy sources to the food web.

Angiosperm biomass passes up the marine food web primarily via detritivores consuming the plant material and (more importantly) the attached microbial communities (Teal 1962, Odum \& de la Cruz 1967, Thayer et al. 1984, Howes et al. 1985, Newell \& Porter 2000). The detritivores are then prey for larger animals (e.g. in marshes: decapods, such as grass shrimp Palaemonetes pugio, and small fish, such as the mummichog Fundulus heteroclitus, and other killifishes) and ultimately support production of recreationally and commercially important finfish, shellfish, waterfowl and wading birds (Teal 1962). The ecological efficiency (consumer production per unit producer production) is low because a high percentage of biomass produced by the plant is broken down by microorganisms (primarily fungi: Newell \& Porter 2000) before it can be assimilated. Benthic meiofauna and macrofauna also directly consume benthic and epiphytic microalgae directly and thus with higher transfer efficiency.

We also employed an alternative trophic level to scale the habitat restoration, field-based estimates of benthic meiofauna plus macrofauna production instead of primary production. Scaling to primary production assumes that all the benefits to animals in the restored habitat are generated by the additional plant production as food. However, the habitat provides other ecological services to animals, such as supplying shelter, nursery areas, and refuge from predators that increase survival and growth (Boesch \& Turner 1984, Heck et al. 2003). For example, while the phytoplankton production in the overlying water is likely the same over eelgrass beds and unvegetated areas, one economically important species, the bay scallop, is found exclusively in seagrass meadows despite its dependence upon phytoplankton for food (Peirson 1983). Thus, bay scallop production would be enhanced by habitat restoration, but not because of enhanced primary production. Benthic animal production in structured habitats is often larger than that which can be accounted for by observed primary production (e.g. Nixon \& Oviatt 1973, Heck et al. 1995). Using benthic faunal production for scaling therefore would implicitly include these habitat services gained. Thus, we used benthic production as an alternative trophic level for scaling restoration.

In the habitat restoration model, each species group injured was assigned a trophic level relative to that of the benthic fauna (implying the herbivore or detritivore trophic level). For species at the same trophic level (e.g. zooplankton), their production was assumed to be equivalent in ecological value. The production loss of small nekton that prey on benthic fauna (e.g. decapods and killifish) was translated to equivalent benthic faunal production loss by dividing by the ecological efficiency of trophic transfer from the prey to the predator. For each step higher in the chain, the trophic transfer efficiency was applied to estimate the production yield (i.e. production loss divided by ecological efficiency for each step in the food web) at that upper trophic level.

Values for production of predator per unit production of prey (i.e. ecological efficiency) for invertebrate and fish consumers of animal prey have been estimated to be 10 to $30 \%$ in both freshwater and marine environments by a number of authors (e.g. Slobodkin 1960, Odum 1971, Steele 1974, Cohen et al. 1982, Jennings et al. 2002). While some have argued that $10 \%$ is the appropriate average value for all marine animals (Pauly \& Christensen 1995), Pimm (1982) indicated that ecological efficiency is $10 \%$ for fish and 21 to $36 \%$ for non-insect invertebrates. Jennings et al. (2002) estimated transfer efficiencies of 3.7 to $12.4 \%$ based on measured standing stock biomass in the North Sea for fishery species of a broad range of sizes. However, if species greater than $512 \mathrm{~g}$ (many of which are intensely fished) are excluded, the efficiency was estimated as $12.4 \%$. Excluding species greater than $256 \mathrm{~g}$ results in a calculated efficiency based on the North Sea sampling data of $27.1 \%$. Thus, the evidence suggests that smaller species, and particularly invertebrates, are more efficient than large fish. In our habitat restoration model, the transfer efficiency of fish and invertebrates $<200 \mathrm{~g}$ was assumed to be $20 \%$, that for 200 to $1000 \mathrm{~g}$ fish to be $10 \%$, and $4 \%$ for fish $>1000 \mathrm{~g}$.

For birds and mammals (which as homeotherms are less efficient), ecological efficiency is much lower, with estimates ranging from 1 to $5 \%$ (McNeill \& Lawton 1970, Steele 1974, Grodzinski \& Wunder 1975, Whittaker 1975, Pimm 1982). In our habitat restoration model, the ecological efficiency of birds and mammals feeding on fish or invertebrate prey was assumed to be $2 \%$.

Equivalent compensatory benthic faunal production produced by the restored habitat was computed as $\mathrm{kg}$ of production lost divided by ecological efficiency for each step in the food web above benthic fauna (termed 
the production yield). Table 4 summarizes the injury (as dry weight) for the 'North Cape' oil spill and the estimated production yield of each trophic level as a percentage of benthic faunal production. The dry weight (DW) equivalent of the injury was assumed to represent $22 \%$ of wet weight (Nixon \& Oviatt 1973). In benthic faunal production equivalents, the majority of the injury was to benthic macrofauna, bivalves, sea stars, crabs, and small fish (cunner). In Table 4 and subsequent tables, lobsters are not included, but bivalves and sea stars are carried forward in the calculations for illustrative purposes and because habitat restoration was considered for these species even though the alternative that was selected involved restocking (French McCay et al. 2003b).

Equivalent compensatory primary production of the restored habitat is the equivalent compensatory benthic production divided by a factor representing the integrated production yield from primary producers to benthic fauna, which is the weighted sum (by fraction of total primary production derived from angiosperms vs benthic microalgae) of the product of the ecological efficiency of transfer from angiosperm to invertebrate detritivore and that from benthic microalgae to benthic herbivore.

In salt marsh stands of Spartina alterniflora, $>95 \%$ of the below-ground primary production is remineralized to $\mathrm{CO}_{2}$ in the sediments, with $<5 \%$ exported as dissolved organic carbon (Howes et al. 1985). Thus, essentially none is transferred to benthic fauna. Assuming that $10 \%$ of the above-ground Spartina production is consumed by terrestrial insects (Kreeger \& Newell 2000 ), $90 \%$ of the above-ground production enters the marsh food web. Newell \& Porter (2000) estimated that 50 to $60 \%$ of Spartina shoot production is transferred to fungal production. The fungi are consumed by the gammaridean amphipod Uhlorchestia spartinophilia to produce an estimated $0.92 \mathrm{~g} \mathrm{DW} \mathrm{m}^{-2} \mathrm{yr}^{-1}$ in Georgia marshes (Covi \& Kneib 1995), with most of the remainder of the fungal production passing through additional microbial degraders before being consumed by benthic meiofauna and macrofauna. Assuming an above-ground Spartina production in Georgia marshes of $1000 \mathrm{~g} \mathrm{DW} \mathrm{m}^{-2} \mathrm{yr}^{-1}$ (Kneib 2003, in this Theme Section), $55 \%$ transfer efficiency to fungi, and $20 \%$ transfer efficiency to $U$. spartinophilia (i.e. joint production yield $=11 \%$ ), $1 \%$ of the above-ground Spartina production is transferred to the amphipod via directly from fungi $\left(900 \mathrm{~g} \mathrm{DW} \mathrm{m}^{-2} \mathrm{yr}^{-1} \times 0.55 \times 0.20 \times 0.01=1 \mathrm{~g}\right.$ DW $\mathrm{m}^{-2} \mathrm{yr}^{-1}$ ). Summarizing multiple stable isotope analyses, Sullivan \& Currin (2000) concluded that benthic microalgae are responsible for $50 \%$ or more of the carbon assimilated by consumer organisms. The production yield from benthic microalgae to benthic fauna is assumed to be $10 \%$ (based on the above review of trophic transfer efficiencies and the likelihood that transfer efficiency from algae to invertebrate would be less than from animal prey). The remaining carbon assimilated by benthic fauna derives from Spartina production that has passed through the microheterotrophic community. The production yield of this pathway is at a maximum $2.2 \%$ ( 0.55 to fungi $x$ 0.20 to microheterotrophs $\times 0.20$ to benthic fauna), but would be lower if more steps are involved in the microbial web. The combined production yield from above-ground Spartina production to benthic meioand macrofauna based on these assumptions is $2.1 \%$. Adding an additional step to the microbial pathway gives a production yield of $0.5 \%$.

Direct grazing on eelgrass leaves is considered relatively unimportant as a trophic pathway in temperate seagrass beds, with the majority (assumed $100 \%$ in our restoration model) of the organic matter produced by eelgrass decomposing and entering the food chain through the detrital pathway (Thayer et al. 1984). We assume that similar transfer efficiencies from angiosperm and epiphytic/benthic microalgal production to benthic faunal production apply in eelgrass beds as for salt marshes. The production yield from benthic and epiphytic microalgae to benthic fauna is assumed to be $10 \%$. Assuming $55 \%$ transfer to fungi and depending on number of consumer steps following that transfer,

Table 4. Summary of injuries by trophic group and production yield from benthic faunal production to the trophic group, based on assumed ecological efficiencies for the trophic steps involved. DW: dry weight

\begin{tabular}{|c|c|c|c|c|}
\hline Species in trophic group & $\begin{array}{l}\text { Total injury } \\
\left(\times 10^{3} \mathrm{~kg} \mathrm{DW}\right)\end{array}$ & $\begin{array}{l}\text { Feeding method } \\
\text { or community }\end{array}$ & $\begin{array}{l}\text { Production } \\
\text { yield (\%) }\end{array}$ & $\begin{array}{l}\text { Compensatory benthic } \\
\text { production }\left(\times 10^{3} \mathrm{~kg}\right)\end{array}$ \\
\hline Large fish & 10 & Bottom feeders & 10 & 99 \\
\hline Bivalves & 83 & Filter feeders & 20 & 417 \\
\hline Sea stars & 7 & Bivalve predators & 4 & 173 \\
\hline Crabs, shrimp, small fish & 39 & Bottom feeders & 20 & 195 \\
\hline Benthic macrofauna & 160 & Benthic fauna & 100 & 160 \\
\hline Pond birds & 0.1 & Bottom feeders & 2 & 5 \\
\hline Total all species & 300 & & & 1050 \\
\hline Total without bivalves and sea stars & 209 & & & 459 \\
\hline
\end{tabular}


the production yield from eelgrass to benthic faunal production is 2.2 to $11 \%$ (6.6\% if half the fungal production is consumed by benthic fauna without an additional microheterotroph step).

The equivalent compensatory production $\left(P_{\mathrm{c}}\right)$ is translated to area of restored habitat $\left(H_{\mathrm{R}}\right)$ by dividing by expected net gain in annual productivity per area in the restored habitat $\left(P_{\mathrm{R}}\right)$ times a discounting factor $(D)$ accounting for the project life (the number of years the restored habitat will exist: $\lambda$ ), and the delay before realizing the benefits. Thus:

$$
\begin{gathered}
H_{\mathrm{R}}=P_{\mathrm{c}} /\left(P_{\mathrm{R}} \times D\right) \\
D=(1+d)^{\rho} \sum_{n=0}^{n=\lambda} F_{n}(1+d)^{-n}
\end{gathered}
$$

where $d$ is the annual discount rate $(0.03), \rho$ is the number of years after the spill when the restoration project begins, and $F_{n}$ is the functional value of the restored habitat $n$ years after planting as a fraction of full function. The discount factors, $(1+d)^{\rho}$ and $(1+d)^{-n}$, decrease the value of the production by $3 \%$ for each year that passes before that production is realized. This follows economic discounting, in that losses and gains in the future are less valued than present production. Including identical discounting on both the injury and restoration sides of the equation allows time lags in both losses and benefits to be appropriately treated in order to measure values lost and gained fixed to a common year.

If the habitat is fully functional from the start of the restoration project (i.e. in the case of preservation), $F_{n}=1$ for all values of $n$, while the value of $\rho$ is the years after the spill the habitat would be lost if it were not preserved. For an expected project life greater than $50 \mathrm{yr}$, the value of $\Sigma(1+d)^{-n}$ approaches 31.6. However, if new habitat was created, there would be a period of 'recovery' while it developed to full function. The recovery curve is assumed sigmoid in shape and to fit to a logistic equation (French et al. 1996a). The sigmoid curve is based on the notion that habitats would develop function slowly at first and then more rapidly, but that the increase in function would level off as an asymptotic full-function level is approached. Alternative functions could also be used, such as a linear increase or one where full-function is never reached. The fraction of full production rate attained by year $n$ after planting, $F_{n}$ is calculated from $y_{\mathrm{r}}=$ years to $99 \%$ of full function, using the following rearrangement of the standard logistic equation:

$$
F_{n}=1 /\left(1+99 \mathrm{e}^{-r n}\right)
$$

where $r=9.19024 / y_{\mathrm{r}}$.

Because restoration involves the replacement of one habitat with another, the production gain $\left(P_{\mathrm{R}}\right)$ is the dif- ference between production in the new and in the replaced habitat. Production gains for transforming subtidal areas into seagrass beds were calculated as the difference between production in shallow subtidal unvegetated habitats and in vegetated habitat. For salt marshes, we assumed that the created marsh would be on land or shoreline (e.g. filled areas) that otherwise provide no net production to the estuarine and marine system, and no accounting was made of any terrestrial system losses that might be of concern in certain locations. However, if, for example, a mud flat were planted to become a marsh, the benthic microalgal production rate for the flat would need to be subtracted from the similar production rate in the resulting marsh. Assuming that mud flats and vegetated portions of marshes have similar benthic microalgal production rates (Sullivan \& Currin 2000), the only net gain in primary production would then derive from the angiosperms.

\section{Credit for increased scavenger production}

The total biomass directly killed during the oil spill remained in the marine and salt pond ecosystems in the form of food for scavengers. We assumed that the killed biomass was consumed by the benthic meiofauna and macrofauna, and so enhanced production of benthos occurred, with the ecological efficiency for this trophic transfer $(20 \%$, defended above) determining the production yield. The resultant scavenger production $\left(235 \times 10^{3} \mathrm{~kg}\right)$ was credited against the production foregone of the benthic fauna, such that the net injury of benthic fauna to be compensated was $729 \times 10^{3} \mathrm{~kg}$. While it may be argued that some of the killed organisms would have eventually provided food for these or other scavengers (e.g. crabs), or may have been subject to microbial degradation, the spill provided an earlier and presumably much larger biomass to scavengers than would have occurred in its absence. Despite failure to correct for the fraction of killed biomass that would have eventually provided food for the scavengers, the amount of credit associated with feeding scavengers was relatively small compared to the total injury. Similarly, no correction was made for the percentages of dead fauna consumed at lower or higher trophic levels than the benthic fauna, which would affect its value when converted to production at the benthic faunal trophic level.

\section{Restoration scale compensatory for the 'North Cape' injuries}

Salt marsh and eelgrass beds were assumed to take 15 and $3 \mathrm{yr}$, respectively, to reach $99 \%$ of full function, 
based on the studies reviewed above. The project lifetime was assumed to be 100 yr (essentially in perpetuity) for both habitats, although an alternative of a $10 \mathrm{yr}$ project life for eelgrass beds was also computed because some areas considered for seagrass restoration would not be protected from degradation of water quality for longer than that time frame. The results were quite sensitive to these assumptions, as illustrated below.

Estimates of above-ground production of Spartina alterniflora are available for several sites in New England. In a Rhode Island marsh, $72 \%$ of the marsh was short $S$. alterniflora with an estimated annual production of $432 \mathrm{~g} \mathrm{DW} \mathrm{m} \mathrm{m}^{-2} \mathrm{yr}^{-1}$, while production in tall S. alterniflora areas ( $7 \%$ of the marsh) and mixed stands of Spartina patens and Distichlis spicata (19\% of the marsh) were 840 and $680 \mathrm{~g} \mathrm{DW} \mathrm{m}^{-2} \mathrm{yr}^{-1}$, respectively (Nixon \& Oviatt 1973). Roman et al. (1990) estimated similar above-ground production rates in low and high marsh areas ranging from 445 to $732 \mathrm{~g} \mathrm{DW}$ $\mathrm{m}^{-2} \mathrm{yr}^{-1}$. Valiela et al. (1976) estimated above-ground production of $420 \mathrm{~g} \mathrm{DW} \mathrm{m}{ }^{-2} \mathrm{yr}^{-1}$ in low marsh and $630 \mathrm{~g} \mathrm{DW} \mathrm{m}^{-2} \mathrm{yr}^{-1}$ in high marsh of the Great Sippewisset salt marsh, Massachusetts. Thus, southern New England salt marsh angiosperm above-ground production averaged over a typical marsh (i.e. as studied by Nixon \& Oviatt 1973) is $500 \mathrm{~g} \mathrm{DW} \mathrm{m}^{-2} \mathrm{yr}^{-1}$.

Benthic microalgal production in the vegetated low marsh area of the Great Sippewisset salt marsh was estimated as $105.5 \mathrm{~g} \mathrm{DW} \mathrm{m}^{-2} \mathrm{yr}^{-1}$, ca. $25 \%$ of aboveground angiosperm production (Van Raalte et al. 1976), and within the range described by Sullivan \& Currin (2000) for USA east coast marshes generally. Benthic microalgal production in unvegetated areas of Delaware marshes was estimated as $84 \mathrm{~g} \mathrm{DW} \mathrm{m}^{-2} \mathrm{yr}^{-1}$ on a creek bank and $202 \mathrm{~g} \mathrm{DW} \mathrm{m}^{-2} \mathrm{yr}^{-1}$ in a salt panne (Sullivan \& Currin 2000, assuming $45 \%$ carbon). Thus, averaging over vegetated and unvegetated areas would likely yield a value close to the $106 \mathrm{~g} \mathrm{DW} \mathrm{m}^{-2}$ $\mathrm{yr}^{-1}$, which was used in the model calculations. Note that there would only be a net gain in benthic microalgal production if the area where marsh is created had not previously been mud flat and/or other habitat producing similar algal production.

Total benthic meiofauna and macrofauna production rates for salt marshes in southern New England were obtained from several sources. Production of macrofauna in unvegetated areas (tidal creeks and channels) of the Great Sippewisset salt marsh averaged $26.9 \mathrm{~g}$ DW $\mathrm{m}^{-2} \mathrm{yr}^{-1}$ (weighted by the areas of different sediment types measured), with production to biomass ratios (P:B) averaging 4.0 (Sarda et al. 1995). Using measured meio- and macroinfaunal biomass from Nixon \& Oviatt (1973) and a P:B ratio of 4, production in vegetated areas of a Rhode Island marsh would be
$7 \mathrm{~g} \mathrm{DW} \mathrm{m}^{-2} \mathrm{yr}^{-1}$. Based on the estimate of $0.9 \mathrm{~g} \mathrm{DW} \mathrm{m}^{-2}$ $\mathrm{yr}^{-1}$ for the gammaridean amphipod from Covi \& Kneib (1995) and molluscan production in Spartina beds in Nova Scotia (eastern Canada) of $6.5 \mathrm{~g} \mathrm{DW} \mathrm{m}^{-2} \mathrm{yr}^{-1}$ from Burke \& Mann (1974), epifaunal production rate in vegetated areas of southern New England marshes was estimated at $18.7 \mathrm{~g} \mathrm{DW} \mathrm{m}^{-2} \mathrm{yr}^{-1}$.

Based on the angiosperm and benthic microalgal production rates entering the marine food web (450 and $106 \mathrm{~g} \mathrm{DW} \mathrm{m}^{-2} \mathrm{yr}^{-1}$, respectively) and the estimated production yield from each to benthic fauna (2.1 and $10 \%$, respectively), expected benthic faunal production is $20.8 \mathrm{~g} \mathrm{DW} \mathrm{m}^{-2} \mathrm{yr}^{-1}$, very close to the estimate based on field sampling. If the production efficiency from benthic microalgae to benthic fauna is actually $20 \%$ (as for invertebrates consuming animal food), the expected benthic faunal production is $31.4 \mathrm{~g} \mathrm{DW} \mathrm{m}^{-2}$ $\mathrm{yr}^{-1}$. This may be a more reasonable estimate given that the benthic macroinfaunal production values for unvegetated areas taken from Sarda et al. (1995) did not include meiofaunal or epibenthic faunal production.

Using $20 \%$ transfer efficiency to small nekton (killifish and shrimp), these benthic production estimates of 18.7, 20.8, and $31.4 \mathrm{~g} \mathrm{DW} \mathrm{m}^{-2} \mathrm{yr}^{-1}$ imply small nekton production of $3.8,4.2$, and $6.3 \mathrm{~g} \mathrm{DW} \mathrm{m}^{-2} \mathrm{yr}^{-1}$, respectively. Based on Kneib's (2003) review of small nekton production in east coast USA marshes (averaged over the entire marsh), fish production is ca. 1 to $2 \mathrm{~g} \mathrm{DW} \mathrm{m}^{-2}$ $\mathrm{yr}^{-1}$ and shrimp production is similar or somewhat higher. Thus, small nekton production is ca. 2 to $4 \mathrm{~g}$ $\mathrm{DW} \mathrm{m} \mathrm{m}^{-2} \mathrm{yr}^{-1}$. Production of transient species that also consume benthic fauna is not included in this computation, but would be less than that of the resident species (Kneib 2003). Assuming 20\% transfer efficiency and one trophic step to the small nekton, the benthic production estimates imply nekton production of $3.8 \mathrm{~g} \mathrm{DW} \mathrm{m}^{-2} \mathrm{yr}^{-1}$ (based on field estimates of benthic biomass and P:B ratios), $4.2 \mathrm{~g} \mathrm{DW} \mathrm{m}^{-2} \mathrm{yr}^{-1}$ (based on 2.1 and $10 \%$ production yield from angiosperm and benthic microalgal production), or $6.2 \mathrm{~g} \mathrm{DW}$ $\mathrm{m}^{-2} \mathrm{yr}^{-1}$ (based on 2.1 and $20 \%$ production yield from angiosperm and benthic microalgal production). In the example calculations below, scaling of salt marsh restoration from primary production was based on 2.1 and $10 \%$ production yield from angiosperm and benthic microalgal production, respectively.

By using stable isotope analyses, Sullivan \& Currin (2000) showed that benthic microalgae are responsible for $50 \%$ or more of the carbon assimilated by consumer organisms on the salt marsh. Using the angiosperm (450 $\mathrm{g} \mathrm{DW} \mathrm{m}^{-2} \mathrm{yr}^{-1}$ ) and benthic microalgal (106 g DW $\mathrm{m}^{-2} \mathrm{yr}^{-1}$ ) production rates and the estimated production yield from each to benthic fauna (2.1 and 10\%, respectively), our food web model indicates that $51 \%$ 
of benthic faunal production results from consumption of benthic microalgae. If the production yield from benthic microalgae to benthic fauna were $20 \%$, the percentage of faunal production resulting from microalgae would become $67 \%$.

Annual primary production rates of eelgrass were assumed to be $1423 \mathrm{~g} \mathrm{DW} \mathrm{m}^{-2} \mathrm{yr}^{-1}$, based on data for Ninigret Pond, Rhode Island, one of the salt ponds affected by the spill (Thorne-Miller \& Harlin 1984). Benthic microalgal production in shallow unvegetated subtidal areas of southern New England lagoons were assumed to be similar to those $<1 \mathrm{~m}$ deep in South Carolina marshes, i.e. $124 \mathrm{~g} \mathrm{DW} \mathrm{m}{ }^{-2} \mathrm{yr}^{-1}$ (Sullivan \& Currin 2000, assuming $45 \%$ carbon). In lower Chesapeake Bay, sediment and epiphytic microalgal production rates in Zostera marina beds were 117.9 and $62.2 \mathrm{~g} \mathrm{C} \mathrm{m}^{-2} \mathrm{yr}^{-1}$, respectively (Buzzelli et al. 1998), totaling $180.1 \mathrm{~g} \mathrm{C} \mathrm{m}^{-2} \mathrm{yr}^{-1}$ (400 $\left.\mathrm{g} \mathrm{DW} \mathrm{m}^{-2} \mathrm{yr}^{-1}\right)$. Thus, the net gain of benthic microalgal production in unvegetated shallow waters where eelgrass might be planted is expected to be $276 \mathrm{~g} \mathrm{DW} \mathrm{m} \mathrm{m}^{-2} \mathrm{yr}^{-1}$.

A review of available benthic macrofaunal production rates in shallow subtidal habitats of similar climate zones as in southern New England suggests benthic faunal production in eelgrass beds of 100 to $300 \mathrm{~g} \mathrm{DW}$ $\mathrm{m}^{-2} \mathrm{yr}^{-1}$ and in shallow unvegetated habitats of $<50 \mathrm{~g}$ DW m ${ }^{-2} \mathrm{yr}^{-1}$ (Heck et al. 1995). Benthic macrofaunal production in a southeastern Massachusetts eelgrass bed was 79 to $175 \mathrm{~g} \mathrm{DW} \mathrm{m}^{-2} \mathrm{yr}^{-1}$ (Heck et al. 1995, assuming $0.8 \mathrm{~g}^{2}$ ash free DW $\mathrm{g}^{-1}$ of dry weight from Nixon \& Oviatt 1973). Fredette et al. (1990) estimated benthic faunal production in eelgrass beds in lower Chesapeake Bay at $200 \mathrm{~g} \mathrm{DW} \mathrm{m}^{-2} \mathrm{yr}^{-1}$ based on estimated production of $42 \mathrm{~g} \mathrm{DW} \mathrm{m}^{-2} \mathrm{yr}^{-1}$ for $20 \%$ of the species by density. Based on the judgment of these authors that their macrofaunal production estimates were underestimates, and using the mid-points of the ranges in the broader literature, we estimated the net gain in an eelgrass bed in Rhode Island to be $200-25=175 \mathrm{~g} \mathrm{DW} \mathrm{m}^{-2} \mathrm{yr}^{-1}$.

Using production rates for eelgrass and microalgae of 1423 and $276 \mathrm{~g} \mathrm{DW} \mathrm{m}^{-2} \mathrm{yr}^{-1}$, respectively and the estimated production yields of 2.2 to $11 \%$ from eelgrass and $10 \%$ from microalgae to benthic fauna, expected benthic faunal production is 59 to $184 \mathrm{~g} \mathrm{DW}$ $\mathrm{m}^{-2} \mathrm{yr}^{-1}$. This calculation assumes that none of the eelgrass production is exported from the bed. If the production yield from benthic microalgae to benthic fauna were actually $20 \%$, the expected benthic faunal production would become 87 to $212 \mathrm{~g} \mathrm{DW} \mathrm{m}^{-2} \mathrm{yr}^{-1}$. The expected benthic faunal production rates decrease to 43-106 g DW m ${ }^{-2} \mathrm{yr}^{-1}$ if $50 \%$ of the eelgrass blade production is not consumed by the benthos within the eelgrass bed (and transfer efficiency of microalgae to benthic fauna is $10 \%$ ). Comparison of the expected benthic faunal production estimates to $175 \mathrm{~g} \mathrm{DW} \mathrm{m}^{-2}$ $\mathrm{yr}^{-1}$ (since the unvegetated area benthic faunal production, $25 \mathrm{~g} \mathrm{DW} \mathrm{m}^{-2} \mathrm{yr}^{-1}$, would be that resulting from phytoplankton production) suggests that eelgrass bed benthic faunal production is greater than that projected by trophic transfer from primary production within the bed, given that a substantial fraction of the eelgrass blade production would likely be exported from the bed by currents. In estimating the net gain from restoration of eelgrass, we recognize that the fraction of eelgrass production exported from the bed will still nourish fauna in the broader area and accomplish the objective of restoring the injury. Thus, 100\% of the production yields from eelgrass $(6.6 \%$, assuming that half the fungal production is consumed by benthic fauna without an additional microheterotroph step) and microalgae $(10 \%)$ to benthic fauna were used as the net gain in the application of the habitat restoration model.

The areas (created or preserved) of salt marsh or eelgrass required for compensation of the injured species were computed based on primary production (Table 5) and on benthic faunal production (Table 6). Planting was assumed to begin $3 \mathrm{yr}$ after the spill and the project life was 100 yr (i.e. the project would be protected and maintained in perpetuity). Although the scale of habitat restoration required for bivalves and sea stars was calculated, these injuries were ultimately restored by direct stocking of bivalves (French McCay et al. 2003b), so the project sizes actually considered were totals without these species. Table 5 is based on the assumption that gains in primary production will result in proportionate gains in secondary production of benthic fauna (18 and $24 \mathrm{~kg} \mathrm{DW} \mathrm{m}^{-2} \mathrm{yr}^{-1}$ for salt marsh and eelgrass, respectively) as the result of additional food resources produced within the restored habitat. The alternative computations for salt marsh based on gains in benthic faunal production $\left(19 \mathrm{~kg} \mathrm{DW} \mathrm{m}{ }^{-2} \mathrm{yr}^{-1}\right.$; Table 6) match those based on primary production, which suggests that salt marsh benthic production is food-limited and that little of that production is based on allochthonous sources. In contrast, the alternative computation for eelgrass based on benthic faunal production (175 kg DW m${ }^{-2} \mathrm{yr}^{-1}$ ) is much higher than that starting with primary production in the bed $(24 \mathrm{~kg}$ DW $\left.\mathrm{m}^{-2} \mathrm{yr}^{-1}\right)$, implying that allochthonous sources contribute substantially and that production enhancement in eelgrass is provided by habitat structure as well as by in situ primary production. Thus, the scaling for eelgrass based on benthic production (Table 6) includes an additional ecosystem service beyond merely augmentation of primary production, which results in lower, but more appropriate, compensatory area requirements. In addition, the much higher benthic productivity in eelgrass beds combined with the similar 
Table 5. Size of a compensatory restoration project using primary production as the scaling metric. Times for development of full function in salt marsh and eelgrass beds were assumed to be 15 and $3 \mathrm{yr}$, respectively. Planting was assumed to begin 3 yr after the spill. Project life was assumed to be $100 \mathrm{yr}$ in all options, i.e. the project is protected and maintained in perpetuity. The land acquisition is for prevention of building on the indicated number of house lots to prevent associated degradation of water quality and resulting loss of eelgrass (see 'Creation versus preservation' for explanation)

\begin{tabular}{|lcccrr|}
\hline Species category & $\begin{array}{c}\text { Preserved salt- } \\
\text { marsh area (ha) }\end{array}$ & $\begin{array}{c}\text { Preserved } \\
\text { eelgrass area (ha) }\end{array}$ & $\begin{array}{c}\text { Land acquisition } \\
\text { (no. of house lots) }\end{array}$ & $\begin{array}{c}\text { Created salt- } \\
\text { marsh area (ha) }\end{array}$ & $\begin{array}{c}\text { Created eelgrass } \\
\text { area (ha) }\end{array}$ \\
\hline Large fish & 16.4 & 2.8 & 22 & 20.3 & 2.9 \\
Bivalves & 69.2 & 11.9 & 91 & 85.9 & 12.3 \\
Sea stars & 28.7 & 4.9 & 38 & 35.6 & 5.1 \\
Crabs, shrimp, small fish & 32.4 & 5.6 & 43 & 40.2 & 5.7 \\
Benthic macrofauna & 26.6 & 4.6 & 35 & 1.1 & 0.2 \\
Pond birds & 0.9 & 0.1 & 230 & 216.2 & 30.8 \\
Total all species & 174.1 & 29.9 & 101 & 94.6 & 13.5 \\
Total without bivalves and sea stars & 76.2 & 13.1 & & \\
\hline
\end{tabular}

Table 6. Size of a compensatory restoration project using benthic faunal production as the scaling metric. Times for development of full function in salt marsh and eelgrass beds were assumed to be 15 and $3 \mathrm{yr}$, respectively. Planting was assumed to begin 3 yr after the spill. Project life was assumed to be $100 \mathrm{yr}$ in all options, i.e. the project is protected and maintained in perpetuity. Land acquisition is for prevention of building on the indicated number of house lots to prevent associated degradation of water quality and resulting loss of eelgrass (see 'Creation versus preservation' for explanation)

\begin{tabular}{|lccccc|}
\hline Species category & $\begin{array}{c}\text { Preserved salt- } \\
\text { marsh area (ha) }\end{array}$ & $\begin{array}{c}\text { Preserved } \\
\text { eelgrass area (ha) }\end{array}$ & $\begin{array}{c}\text { Land acquisition } \\
\text { (no. of house lots) }\end{array}$ & $\begin{array}{c}\text { Created salt- } \\
\text { marsh area (ha) }\end{array}$ & $\begin{array}{c}\text { Created eelgrass } \\
\text { area (ha) }\end{array}$ \\
\hline Large fish & 18.2 & 1.9 & 15 & 22.6 & 2.0 \\
Bivalves & 77.1 & 8.2 & 63 & 95.8 & 8.5 \\
Sea stars & 32.0 & 3.4 & 26 & 39.7 & 3.5 \\
Crabs, shrimp, small fish & 36.1 & 3.9 & 30 & 34.9 & 3.0 \\
Benthic macrofauna & 29.6 & 3.2 & 24 & 1.2 & 0.1 \\
Pond birds & 1.0 & 0.1 & 1 & 241.0 & 21.4 \\
Total all species & 194.1 & 20.7 & 70 & 105.5 & 9.4 \\
Total without bivalves and sea stars & 85.0 & 9.1 & & \\
\hline
\end{tabular}

cost per acre for implementing restoration (French et al. 1996a) suggest that eelgrass restoration is more cost-effective than salt marsh restoration, particularly if land purchase costs need to be included in a salt marsh project.

If eelgrass beds were to be created in the salt ponds affected by the spill, the water quality would need to be sufficient to allow eelgrass beds to develop and remain healthy. However, in Ninigret Pond, for example, eelgrass has declined in recent years because of eutrophication (Short et al. 1996). Thus, water quality improvements would be a prerequisite for any restoration plan involving eelgrass bed creation in Ninigret Pond (as well as many other coastal areas). Pervasive decline in water quality in coastal waters, as well as the need for long-term maintenance of restored habitats, suggests that an assumed project life of $100 \mathrm{yr}$, as used in the calculations presented in Tables $5 \& 6$, is optimistic. The impacts of alternative assumptions about the duration of the project were examined (summarized in Table 7). Because of discounting future contributions, benefits in the first few years after restoration are more valuable and varying project life span does not affect benefits proportionately. Nevertheless, restoration requirements increase dramatically if the project is not expected to be sustained for more than a decade, particularly if the restored habitat requires several years to achieve full functionality (e.g. saltmarsh where results were calculated for 10, 15 and $20 \mathrm{yr}$ development times). The sensitivities to the assumed project life and the development time of the restored habitat demonstrate the importance of longterm adaptive management based on monitoring to realize maximum benefits of restoration.

Preservation of eelgrass habitat was the selected restoration alternative for the 'North Cape' oil spill, in part because maintenance of water quality issues and prevention of eelgrass loss in the coastal ponds had been long-term objectives of local managers. The scaling (Tables 5 \& 6) employed Short et al.'s (1996) empirical relationship (linear regression) between numbers of houses in the watershed and loss of area of eelgrass habitat in Ninigret Pond: $1300 \mathrm{~m}^{2}$ of eelgrass habitat lost per house. Computation of the acreage of 
Table 7. Area (ha) of salt marsh or eelgrass restoration required for compensation of all species in Table 4 under varying assumptions: PP, based on primary production gained; BP, based on benthic faunal production gained; years for development of full function in the habitat; and project life for the restoration (years the habitat will be protected or maintained). Planting was assumed to begin 3 yr after the spill in all cases

\begin{tabular}{|c|c|c|c|c|c|c|c|}
\hline Action & $\begin{array}{l}\text { Project } \\
\text { life (yr) }\end{array}$ & $\begin{array}{c}\text { Marsh PP } \\
(15 \text { yr })\end{array}$ & $\begin{array}{c}\text { Marsh BP } \\
(15 \mathrm{yr})\end{array}$ & $\begin{array}{c}\text { Marsh PP } \\
(10 \mathrm{yr})\end{array}$ & $\begin{array}{c}\text { Marsh PP } \\
(20 \mathrm{yr})\end{array}$ & $\begin{array}{l}\text { Eelgrass } \\
\text { PP (3 yr) }\end{array}$ & $\begin{array}{l}\text { Eelgrass } \\
\text { BP (3 yr) }\end{array}$ \\
\hline Created & 10 & 2160 & 2407 & 1246 & 3992 & 125 & 87 \\
\hline Created & 20 & 630 & 703 & 511 & 801 & 68 & 47 \\
\hline Created & 30 & 409 & 456 & 355 & 475 & 51 & 35 \\
\hline Created & 40 & 324 & 362 & 290 & 364 & 43 & 30 \\
\hline Created & 50 & 281 & 313 & 255 & 311 & 38 & 26 \\
\hline Created & 100 & 216 & 241 & 200 & 233 & 31 & 21 \\
\hline Preserved & 100 & 174 & 194 & 174 & 174 & 30 & 21 \\
\hline
\end{tabular}

land required for compensation included only land zoned for and suitable for development because otherwise purchase would not afford additional protection of water quality.

\section{DISCUSSION}

Minello et al. (2003) showed that seagrass beds had higher nursery value, as measured by fish and crustacean growth and survival, than saltmarsh habitat, and both were more valuable than open water. Our estimates of gains in benthic faunal production in eelgrass and salt marsh restorations in southern New England are consistent with their findings. In addition, our trophic energetics model suggests that the percentage of benthic secondary production resulting from benthic microalgae is $50 \%$ or more in salt marshes, in agreement with the conclusions of Sullivan \& Currin (2000). For eelgrass beds, the percentage of benthic faunal production generated by benthic and epiphytic microalgae is dependent on the fraction of eelgrass production consumed within the bed. If $100 \%$ of the eelgrass were consumed locally, the percentage of carbon assimilated via the microalgal pathway would be 15 to $47 \%$. However, if $50 \%$ of the eelgrass were exported from the bed, microalgae would account for 26 to $64 \%$ of benthic secondary production. Clearly, additional research is needed to determine the carbon and energy budgets of eelgrass beds. The proportion of eelgrass blades retained within a bed almost certainly will be shown to vary with physical transport regime and bed size.

The critical importance of salt mashes, seagrass beds, and other structured habitats to many estuarine and marine species for reproduction, foraging and shelter, combined with the pervasive decline in these habitats due to pollution and other environmental impacts, makes them likely and appropriate targets of restoration for mitigation. Considerable research has identi- fied the requirements for successful restoration of salt marshes and eelgrass beds (Seneca \& Broome 1992, Matthews \& Minello 1994, Fonseca et al. 1998). The trophic energetics model developed here provides a novel approach for estimating the appropriate scale of the restoration to be compensatory, based on food-web structure, transfer efficiencies, and economic discounting. The estimation of biological losses involves demographic modeling to include not only the biomass of organisms that are killed directly, but also the production foregone. Restoration employs food-web modeling to replace losses in biotic production with enhancements at the same or energetically equivalent trophic levels. Finally, the habitat restoration model uses the same scaling metric on both the injury and the restoration side of the equation (i.e. production by trophic level), which is essential for the restoration to be compensatory.

There is substantial uncertainty associated with estimating the benefits of habitat restoration to the injured biota. The quantitative scaling methods developed here are based solely on production, justified by arguing that production serves as a proxy for most important ecosystem functions, including provision of food, and nutrient cycling. One limitation to this approach is a failure to include organism size in the accounting. A way to address this limitation would be to partition the trophic-level analysis not only by species but also by size class. In addition, the food web could be more accurately depicted by using weighted average trophic steps (such as in Odum \& Heald 1975). Finally, benefits of restoration could be assessed using other measures of habitat function as future research more clearly identifies and quantifies ecosystem services.

Compensatory restoration on a species-by-species basis could be carried out in a fashion designed to replace ecosystem and human services provided by all injured species. However, because of the operation of complex webs of interactions among species within the ecosystem, projects that benefit one species may adversely impact others. For example, protection of a 
prey species from predators would presumably reduce production of the predators. The use of habitat restoration to restore many species simultaneously is more likely to achieve the intended net benefits to the ecosystem as a whole and help maintain biodiversity, important goals of environmental conservation (Wilson \& Peters 1988).

Habitat restoration also involves a substantial degree of uncertainty. Creating one desired habitat involves destroying an equal area of another. Careful consideration needs to be given to the loss of the original habitat and the direct and interactive role that this habitat plays in the marine ecosystem. In response to uncertainty in estimating the necessary scale of restoration needed for compensation, and in performance of the restoration project, quantitative monitoring metrics (such as achieving certain levels of productivity at defined times) should be included in restoration planning (Fonseca et al. 1998, Julius 1999). The degree of success in restoring ecosystem functions and services depends on the ability to adaptively manage the restoration efforts based on results of a thorough monitoring plan (Fonseca et al. 1998). In mitigating for environmental injuries, uncertainty is often handled by requiring the scale of mitigation to exceed what is necessary to replace the loss by some mitigation ratio that increases with uncertainty. For example, ratios of 2 to 3 acres of restoration for each acre of salt marsh lost are commonly used (Thayer 1992). The trophic scaling model developed here may help reduce the uncertainty in habitat restoration by using growing scientific understanding of habitat function to quantify benefits to the ecosystem.

Acknowledgements. Support for this work was provided by NOAA (the National Oceanographic and Atmospheric Administration). We thank Carol-Ann Manen and John Catena for their guidance and all the 'North Cape' oil spill trustees for thoughtful contributions. Mike Donlan provided administrative assistance and critical review. Comments and editorial suggestions by C. H. Peterson and anonymous reviewers are gratefully acknowledged.

\section{LITERATURE CITED}

Adam P (1993) Saltmarsh ecology. Cambridge University Press, Cambridge

Beck MW, Heck KL Jr, Able KW, Childers DL and 9 others (2001) The identification, conservation, and management of estuarine and marine nurseries for fish and invertebrates. Bioscience 51:633-641

Beck MW, Heck KL Jr, Able KW, Childers DL and 9 others (2003) The role of nearshore ecosystems as fish and shellfish nurseries. Issues in Ecology No. 11. Ecological Society of America, Washington, DC (available at www. esa.org/ sbi/sbi_issues/)

Boesch DF, Turner RE (1984) Dependence of fishery species on salt marshes: the role of food and refuge. Estuaries 7 : 460-468

Burke MV, Mann KH (1974) Productivity and production: biomass ratios of bivalve and gastropod populations in an eastern Canadian estuary. J Fish Res Board Can 31: 167-177

Burkholder JM, Mason KM, Glasgow HB Jr (1992) Watercolumn nitrate enrichment promotes decline of eelgrass Zostera marina: evidence from seasonal mesocosm experiments. Mar Ecol Prog Ser 81:163-178

Buzzelli CP, Wetzel RL, Meyers MB (1998) Dynamic simulation of littoral zone habitats in lower Chesapeake Bay. 2. Seagrass habitat primary production and water quality relationships. Estuaries 21:673-689

Cobb JS, Clancy M, Wahle RA (1999) Habitat-based assessment of lobster abundance: a case study of an oil spill. Am Fish Soc Symp 22:285-298

Cohen EB, Grosslein MD, Sissenwine MP, Steimle F, Wright WR (1982) Energy budget of Georges Bank. In: Mercer MC (ed) Multispecies approaches to fisheries management advice. Can Spec Publ Fish Aquat Sci 59:95-107

Covi MP, Kneib RT (1995) Intertidal distribution, production dynamics and production of the amphipod Uhlorchestia spartinophilia in a Georgia, USA, salt marsh. Mar Biol 121: $447-455$

Currin CA, Newell SY, Paerl HW (1995) The role of standing dead Spartina alterniflora and benthic microalgae in salt marsh food webs: considerations based on multiple stable isotope analysis. Mar Ecol Prog Ser 121:99-116

Fonseca MS, Kenworthy WJ, Colby DR, Rittmaster KA, Thayer GW (1990) Comparison of fauna among natural and transplanted eelgrass Zostera marina meadows: criteria for mitigation. Mar Ecol Prog Ser 65:251-264

Fonseca MS, Kenworthy WJ, Thayer GW (1998) Guidelines for the conservation and restoration of seagrasses in the United States and adjacent waters. NOAA Coastal Ocean Program Decision Analysis Series No 12, NOAA Coastal Ocean Office, Silver Spring, MD

Fredette TJ, Diaz RJ, van Montfrans J, Orth RJ (1990) Secondary production within a seagrass bed (Zostera marina and Ruppia maritima) in lower Chesapeake Bay. Estuaries 13:431-440

French DP, Rines H (1998) Estimation of losses in the salt ponds resulting from water column and sediment acute toxicity from the North Cape oil spill. NOAA Damage Assessment Center, Silver Spring, MD (part of case administrative record, available at www.darp.noaa. gov/ neregion/ncape.htm)

French DP, Reed M, Jayko K, Feng S and 16 others (1996a) The CERCLA type A natural resource damage assessment model for coastal and marine environments (NRDAM/ CME), technical documentation, Vol I-V. Final Report, Contract No. 14-0001-91-C-11, Office of Environmental Policy and Compliance, US Department of the Interior, Washington, DC

French DP, Rines H, Gifford D, Keller A and 7 others (1996b) Primary restoration: guidance document for natural resource damage assessment under the Oil Pollution Act of 1990. NOAA Damage Assessment and Restoration Program, Silver Spring, MD

French McCay DP (2002) Development and application of an oil toxicity and exposure model, OilToxEx. Environ Toxicol Chem 21:2080-2094

French McCay DP (2003) Development and application of damage assessment modeling: example assessment for the North Cape oil spill. Mar Pollut Bull 47:341-359

French McCay DP, Gibson M, Cobb JS (2003a) Scaling restoration of American lobsters: combined demographic and discounting model for an exploited species. Mar Ecol Prog Ser 264:177-196 (in this Theme Section) 
French McCay DP, Peterson CH, DeAlteris JJ, Catena J (2003b) Restoration that targets function as opposed to structure: replacing lost bivalve production and filtration. Mar Ecol Prog Ser 264:197-212 (in this Theme Section)

Grodzinski W, Wunder BA (1975) Ecological energetics of small mammals. In: Golley FB, Petrusewicz K, Ryszkowski L (eds) Small mammals: their productivity and population dynamics. Cambridge University Press, Cambridge, p 173-204

Heck KL Jr, Orth RJ (1980) Seagrass habitats: the roles of habitat complexity, competition and predation in structuring associated fish and motile macroinvertebrate assemblages. In: Kennedy VS (ed) Estuarine perspectives. Academic Press, New York, p 449-464

Heck KL Jr, Able KW, Roman CT, Fahay MP (1995) Composition, abundance, biomass, and production of macrofauna in a New England estuary: comparisons among eelgrass meadows and other nursery habitats. Estuaries 18: 379-389

Heck KL Jr, Hays C, Orth RJ (2003) A critical evaluation of the nursery role hypothesis for seagrass meadows. Mar Ecol Prog Ser 253:123-136

Hinga KR (1988) Seasonal predictions for pollutant scavenging in two coastal environments using a model calibration based on Thorium scavenging. Mar Environ Res 26: 97-112

Hinga KR (1997) Concentrations over time of North Cape oil in water and sediments in Rhode Island's south shore ponds. Report by University of Rhode Island, Narragansett, to NOAA Damage Assessment Center, Silver Spring, MD (part of case administrative record, available at www. darp.noaa.gov/neregion/ncape.htm)

Howes BL, Dacey JWH, Teal JM (1985) Annual carbon mineralization and belowground production of Spartina alterniflora in a New England salt marsh. Ecology 66:595-605

Jennings S, Warr KJ, Mackinson S (2002) Use of size-based production and stable isotope analyses to predict trophic transfer efficiencies and predator-prey body mass ratios in food webs. Mar Ecol Prog Ser 240:11-20

Julius B (1999) Discounting and the treatment of uncertainty in natural resource damage assessment. Technical Paper 99-1, NOAA Damage Assessment and Restoration Program, Silver Spring, MD

Kneib RT (1997) The role of tidal marshes in the ecology of estuarine nekton. Oceanogr Mar Biol Annu Rev 35: $163-220$

Kneib RT (2003) Bioenergetic and landscape considerations for scaling expectations of nekton production from intertidal marshes. Mar Ecol Prog Ser 264:279-296 (in this Theme Section)

Kreeger DA, Newell RIE (2000) Trophic complexity between producers and invertebrate consumers in salt marshes. In: Weinstein MP, Kreeger DA (eds) Concepts and controversies in tidal marsh ecology. Kluwer Academic Publishers, Dordrecht, p 187-220

Matthews GA, Minello TJ (1994) Technology and success in restoration creation, and enhancement of Spartina alterniflora marshes in the United States, Vol 2. Inventory and Human Resources Directory. NOAA Coastal Ocean Program Decision Analysis Series No 2. NOAA Coastal Ocean Office, Silver Spring, MD

McNeill S, Lawton JH (1970) Annual production and respiration in animal populations. Nature 225:472-474

Minello TJ, Webb JW (1997) Use of natural and created Spartina alterniflora salt marshes by fishery species and other aquatic fauna in Galveston Bay, Texas, USA. Mar Ecol Prog Ser 151:165-179
Minello TJ, Zimmerman RJ (1992) Utilization of natural and transplanted Texas salt marshes by fish and decapod crustaceans. Mar Ecol Prog Ser 90:273-285

Minello TJ, Able KW, Weinstein MP, Hays CG (2003) Salt marshes as nurseries for nekton: testing hypotheses on density, growth and survival through meta-analysis. Mar Ecol Prog Ser 246:39-59

Moy LD, Levin LA (1991) Are Spartina marshes a replaceable resource? A functional approach to evaluation of marsh creation efforts. Estuaries 14:1-16

Newell SY, Porter D (2000) Microbial secondary production from salt marsh-grass shoots, and its known and potential fates. In: Weinstein MP, Kreeger DA (eds) Concepts and controversies in tidal marsh ecology. Kluwer Academic Publishers, Dordrecht, p 159-185

Nixon SW, Oviatt CA (1973) Ecology of a New England salt marsh. Ecol Monogr 43:463-498

NOAA (National Oceanic and Atmospheric Administration) (1997) Natural resource damage assessment guidance document: scaling compensatory restoration actions (Oil Pollution Act of 1990). NOAA Damage Assessment Center, Silver Spring, MD

NOAA (National Oceanic and Atmospheric Administration) (1999) Habitat equivalency analysis: an overview. NOAA Damage Assessment Center, Silver Spring, MD

NOAA (National Oceanic and Atmospheric Administration) (2002) Natural resource damage assessments, final rule. US Federal Register 67(190):61483-61493 (available at http://wais.access.gpo.gov [DOCID:fr01oc02-8])

NOAA (National Oceanic and Atmospheric Administration), Rhode Island Department of Environmental Management, US Department of the Interior, and US Fish and Wildlife Service (1999) Restoration plan and environmental assessment for the January 19, 1996 North Cape oil spill. Revised Draft for Public Comment, NOAA, Silver Spring, MD (available at www.darp.noaa.gov/neregion/ncape.htm)

Odum EP (1971) Fundamentals of ecology. WB Saunders, Philadelphia

Odum E, de la Cruz A (1967) Particulate organic detritus in a Georgia salt marsh-estuarine ecosystem. In: Lauff G (ed) Estuaries. American Association for the Advancement of Science Publication No. 83, Washington, DC, p 383-388

Odum WE, Heald EJ (1975) The detritus based food webs of an estuarine mangrove. In: Cronin LE (ed) Estuarine research, Vol I. Chemistry, biology and the estuarine system. Academic Press, New York, p 265-286

Orth RJ, Moore KA (1983) Chesapeake Bay-an unprecedented decline in submerged aquatic vegetation. Science 222:51-53

Pauly D, Christensen V (1995) Primary production required to sustain global fisheries. Nature 374:255-257

Peirson WM (1983) Utilization of eight algal species by the bay scallop, Argopecten irradians concentricus (Say). J Exp Mar Biol Ecol 68:1-11

PERL (Pacific Estuarine Research Laboratory) (1990) A manual for assessing restored and natural coastal wetlands with examples from southern California. California Sea Grant Report No. T-CSGCP-021, La Jolla, CA

Pimm SL (1982) Food webs. Chapman \& Hall, New York

Roman, CT, Able KW, Lazzari MA, Heck KL (1990) Primary productivity of angiosperm and macroalgae dominated habitats in a New England salt marsh: a comparative analysis. Estuar Coast Shelf Sci 30:35-45

Ryther JH (1969) Photosynthesis and fish production in the sea. Science 166:72-76

Sarda R, Foreman K, Valiela I (1995) Macroinfauna of a 
southern New England salt marsh: seasonal dynamics and production. Mar Biol 121:431-445

Seneca ED, Broome SW (1992) Restoring tidal marshes in North Carolina and France. In: Thayer GW (ed) Restoring the nation's marine environment. Maryland Sea Grant College Program, College Park, MD, p 53-78

Short FT, Burdick DM (1996) Quantifying eelgrass habitat loss in relation to housing development and nitrogen loading in Waquoit Bay, Massachusetts. Estuaries 19:730-739

Short FT, Burdick DM, Kaldy JE (1995) Mesocosm experiments quantify the effects of eutrophication on eelgrass, Zostera marina. Limnol Oceanogr 40:740-749

Short FT, Burdick DM, Granger S, Nixon SW (1996) Longterm decline in eelgrass, Zostera marina L., linked to increased housing development. In: Kuo J, Phillips RC, Walker DI, Kirkman H (eds) Seagrass biology. Proc Int Workshop, Rottnest Island, Western Australia, 25-29 January 1996. University of Western Australia, Nedlands, WA, p 291-298

Slobodkin LB (1960) Ecological energy relationships at the population level. Am Nat 95:213-236

Steele JH (1974) The structure of marine ecosystems. Harvard University Press, Cambridge, MA

Sullivan MJ, Currin CA (2000) Community structure and functional dynamics of benthic microalgae in salt marshes. In: Weinstein MP, Kreeger DA (eds) Concepts and controversies in tidal marsh ecology. Kluwer Academic Publishers, Dordrecht, p 81-106

Teal JM (1962) Energy flow in the salt marsh ecosystem of Georgia. Ecology 43:614-624

Thayer GW (ed) (1992) Restoring the nation's marine environ-

Editorial responsibility: Charles Peterson (Contributing Editor), Morehead City, North Carolina, USA ment. Maryland Sea Grant College Program, College Park, MD

Thayer GW, Kenworthy WJ, Fonseca MS (1984) The ecology of eelgrass meadows of the Atlantic coast: a community profile. Report No. FWS/OBS-84/02, US Fish and Wildlife Service, Washington, DC

Thorne-Miller B, Harlin MM (1984) The production of Zostera marina L. and other submerged macrophytes in a coastal lagoon in Rhode Island, USA. Bot Mar 27:539-546

Valiela I, Teal JM, Persson NY (1976) Production and dynamics of experimentally enriched salt marsh vegetation: below ground biomass. Limnol Oceanogr 21:245-252

Van Raalte CD, Valiela I, Teal JM (1976) Production of epibenthic salt marsh algae: light and nutrient limitation. Limnol Oceanogr 21:862-872

Warren RS, Fell PE, Rozsa R, Brawley AH, Orsted AC, Olson ET, Swamy V, Niering WA (2002) Salt marsh restoration in Connecticut: 20 years of science and management. Restor Ecol 10:497-513

Whittaker RH (1975) Communities and ecosystems, 2nd edn. MacMillan Publishing, New York

Williams GD, Zedler JB (1999) Fish assemblage composition in constructed and natural tidal marshes of San Diego Bay: relative influence of channel morphology and restoration history. Estuaries 22:702-716

Wilson EO, Peters FM (eds) (1988) Biodiversity. National Academy Press, Washington, DC

Zedler JB (1992) Restoring cordgrass marshes in southern California. In: Thayer GW (ed) Restoring the nation's marine environment. Maryland Sea Grant College Program, College Park, MD, p 7-51

Submitted: August 4, 2003; Accepted: November 24, 2003 Proofs received from author(s): December 9, 2003 